\title{
The Episcopal Ministry of Reverend Kazimierz Świątek (1914-2011)
}

This article details the pastoral ministry of Archbishop Kazimierz Świątek, who witnessed to Christ in Belarus as priest for fifty-two years and as an archbishop and cardinal for almost twenty years. After Soviet oppression in Belarus ceased and when Archbishop Kazimierz Świątek became canonically responsible for the Metropolitan Archdiocese of Mińsk-Mohilev and the Diocese of Pińsk, the institutional Church and faith of the people barely existed in these locations. By the time Archbishop Świątek retired from his episcopal ministry, however, the ecclesiastical province had all the institutions necessary to function normally, and the churches were filled with the faithful. Given the exponential growth of the faithful and institutional Church under Archbishop Świątek's care, his pastoral ministry as a bishop merits particular attention and Archbishop Świątek himself deserves to be included among the long list of zealous bishops of the Church of Christ. Fr. Świątek's earlier ministry as a priest has been analyzed in a previous article. ${ }^{1}$

Key words: shepherd, bishop, ministry, kerygma, evangelization, spiritual desolation, communism, rebuilding of the Church, the needs of the faithful, Pińsk, Mińsk-Mohilev.

\section{Metropolitan Archbishop and Apostolic Administrator}

At noon on Saturday, April 13, 1991, in St. Francis Xavier church Bishop Tadeusz Kondrusiewicz, the Administrator of the Diocese of

SeeS.M.Królak, "Wierność powołaniu—ksiądz Kazimierz Świątek(1914-2011),” Rocznik Teologii Katolickiej, vol. XV, no. 1 (2016): 149-179. 
History of the Church

Mińsk; Fr. Kazimierz Świątek, the Vicar General of the Diocese of Pinsk and pastor of Our Lady of the Assumption parish in Pinsk for 37 years; and Fr. Alexander Kaszkiewicz, the pastor of Holy Spirit parish in Vilnius for 10 years, read Pope John Paul II's bull declaring the new organization and nominations of bishops for the Church in Belarus. At the same time, news from the Vatican revealed that Pope John Paul II had appointed new bishops and erected new dioceses within the Soviet Union.

The new Metropolitan Archdiocese of Mińsk-Mohilev covered the entire area of (and only) the Belarusian Soviet Socialist Republic (BSSR). According to the bull Ex quadam praeteritorum, ${ }^{2}$ Mińsk became the capital of the new archdiocese, which territories included parts of the Archdiocese of Mohilev, the Archdiocese of Vilnius, and the Diocese of Mińsk. In the papal bull Qui operam damus, ${ }^{3}$ Pope John Paul II simultaneously established the Diocese of Grodno, the capital of which was Grodno, as a suffragan of the Metropolitan Archdiocese of Mińsk-Mohilev. Grodno's St. Francis Xavier parish church subsequently became the cathedral. Another papal bull, Quia ob rerum, ${ }^{4}$ changed the boundaries of the Diocese of Pinsk, making it a suffragan of the Metropolitan Archdiocese of Mińsk-Mohilev (until then it had belonged to the Metropolitan Archdiocese of Vilnius) and establishing its capital in Pińsk. The part of the Diocese of Pińsk that was located in Poland ceased to belong to this Diocese, while Nowogródek region was also separated from it and incorporated into the newly established Diocese of Grodno. The new church boundaries announced by the papal bulls were determined according to the state's administrative division of the BSSR. The Archdiocese of Mińsk-Mohilev included the districts (voivodeships, oblasts) of Mińsk, Vitebsk, and Mogilev, the Diocese of Pinsk included the districts of Brest and Homel, and the Diocese of Grodno, included the district of Grodno. Within the Diocese

2 John Paul II, bull "Ex quadam praeteritorum, Constittutiones Apostolicae. I. Minscensis-Mohiloviensis Latinorum. Minscensis-Mohiloviensis Latinorum conditur archidioecessis," in Acta Apostolicae Sedis: Commentarium Officiale, vol. 83, no. 7 (Romae: Typis Polygottis Vaticanis, 1991), 540-541. Hereafter referred to as Acta.

3 John Paul II, bull "Qui operam damus, Constittutiones Apostolicae. I. Minscensis-Mohiloviensis Latinorum. Minscensis-Mohiloviensis Latinorum conditur archidioecessis," in Acta Apostolicae Sedis: Commentarium Officiale, vol. 83, no. 7 (Romae: Typis Polygottis Vaticanis, 1991), 540-542.

4 John Paul II, bull "Quia ob rerum, Constittutiones Apostolicae. I. MinscensisMohiloviensis Latinorum. Minscensis-Mohiloviensis Latinorum conditur archidioecessis," in Acta Apostolicae Sedis: Commentarium Officiale, vol. 83, no. 7 (Romae: Typis Polygottis Vaticanis, 1991), 542-543. 
of Grodno, which had the greatest number of Catholics and the bestpreserved parish structure, there were 85 parishes that had hitherto territorially belonged to the Archdiocese of Vilnius, the Diocese of Pińsk (4 parishes), and the Diocese of Eomża (7 parishes). ${ }^{5}$

Fr. Kazimierz Świątek was appointed the Archbishop of the Metropolitan Archdiocese of Mińsk-Mohilev. He, as the new Metropolitan, also became the administrator of the Diocese of Pinsk, ad nutum Sanctae Sedis. Fr. Alexander Kaszkiewicz became the first Bishop of the Diocese of Grodno, ${ }^{6}$ while Fr. Tadeusz Kondrusiewicz became the Archbishop and Apostolic Administrator of the European part of Russia, and his episcopal seat was located in Moscow. ${ }^{7}$ Fr. Kazimierz Świątek was 76 years old when he was appointed Metropolitan. Notably, according to the Code of Canon Law, a bishop must resign from his office at the age of 75 .

On Tuesday, May 21, 1991, Fr. Kazimierz Świątek received his episcopal ordination in the cathedral in Pińsk. When the consecration began, Fr. Kazimierz Świątek cried as he lay on the floor of the cathedral with his arms outstretched like a cross. ${ }^{8}$ Archbishop Tadeusz Kondrusiewicz was the principal consecrator and Bishop Władysław Jędruszuk from Drohiczyn, ${ }^{9}$ Bishop Edward Kisiel from Bialystok, ${ }^{10}$

$5 \quad$ Based on the author's calculations. In 1991, this idea was realized even before World War II had begun. During the 1930s, the local faithful and clergy began efforts both in Rome and with the leaders of the Second Polish Republic to establish a diocese. The enlightened inhabitants of Grodno wanted to elevate the areas rank and religious prestige and improve pastoral care for the faithful who were under the hostile communist influence. The Church approved this initiative and made its final decision in August 1939. However, the establishment of the new diocese was prevented due to Soviet aggression, which occurred on September 17, 1939.

6 See Acta, 601.

7 Ibid.

8 Based on the testimonies of Cardinal Świątek and other witnesses, TS, found in the Cardinal Świątek's personal archives (hereafter abbreviated as APKS).

Władysław Jędruszuk (1918-1994), served from 1962-1967 as auxiliary bishop in Drohiczyn; as apostolic administrator for the Diocese of Pinsk from 1967-1991; and on June 5, 1991 was named the first bishop of the Diocese of Drohiczyn. See P. Nitecki, Biskupi Kościoła w Polsce w latach 965-1999: słownik biograficzny (Warsaw: Instytut Wydawniczy PAX 2000), 184.

10 Edward Kisiel (1918-1993), was the titular bishop of Limata and apostolic administrator of the Archdiocese of Vilnius from 1976-1991. On June 5, 1991, he was named the first bishop of the Diocese of Bialystok, and on March 25, 1992 he was named the metropolitan archbishop of Bialystok. See P. Nitecki, Biskupi, 202-203. 
History of the Church

and Archbishop Francisco Colasuonno-the apostolic nuncio to the Soviet Union co-consecrated. Fr. Kazimierz Świątek's ordination was the first episcopal ordination to ever take place in the Pińsk cathedral and on Belarusian land. After the consecration, a solemn ingress into the cathedral took place.

On May 25, Archbishop Kazimierz Świątek took part in the episcopal ordination of Fr. A. Kaszkiewicz in the cathedral in Grodno. On that day the ecclesiastical province of Belarus became fully operational in accordance with the Code of Canon Law. The following day, Archbishop Świątek participated in the first meeting of Belarusian bishops along with Nuncio F. Colasuonno and representatives of the Belarusian government. The Belarusian authorities and the Belarusian National Front did not accept the papal decisions and did not recognize the office held by Archbishop Świątek, as evidenced by the fact that they called him "Mr. Świątek."

On June 14, 1991, Archbishop Świątek led the solemn ingress into the archcathedral in the capital of Belarus. The entrance into Mińsk was also symbolic because there were no traces left of the Cathedral of the Most Holy Name of Mary, where the last Mass had been celebrated in 1948. Instead, a sports center named "Spartak [Spartacus Club]" was built in its place. Although the solemn entrance took place at Sts. Simon and Helena church, it symbolically occurred on the steps of the "sports palace."

Archbishop K. Świątek's very solemn ingress into the Archcathedral of the Assumption of the Blessed Virgin Mary and St. Stanislaw, Bishop and Martyr, took place on Sunday, July 7 in Mohilev. Since there was no place to house the Archdiocese in Mińsk, the work of the archdiocese was centered in Pińsk, where the Archbishop lived in a tiny room in a wooden house on Shevchenko Street.

On January 17, 1992, Archbishop Kazimierz Świątek received the pallium from the Apostolic Nuncio Archbishop F. Colasuonno during the solemn liturgy in the cathedral in Mińsk.

On October 19, 1994, the Council for Religious Affairs of the Council of Ministers of the Republic of Belarus surprisingly approved the Statutes of the Archdiocese of Mińsk-Mohilev. ${ }^{11}$ This meant that the Catholic Church in Belarus became a legal entity in accordance with the structure and personal decisions that were canonically introduced on April 13, 1991. There are grounds to believe that the Council's

11 Rady ds. Religii przy Radzie Ministrów Republiki Białoruś [Protocol no. 5, Council on Religion for the Council of Ministers of the Republic of Belarus] (10.19.1994); see Mińsko-Mohylewski Przeglad Archidiecezjalny (MMPA), vol. 1, no. 1 (1998): 55 . 
sudden decision was due to Archbishop Świątek's nomination as cardinal, about which the Belarusian authorities had to have found out. Pope John Paul II announced the new cardinals on October 30, 1994 before he prayed the Angelus, and the Archbishop of Minsk-Mohilev was among them. The announcement radically changed the Belarusian authorities' attitude towards Archbishop Świątek. ${ }^{12}$ From then on, none of the authorities dared to address the cardinal by any title other than "Your Eminence" or "Gaspadin Cardinal." All Belarusian newspapers, radio, and television stations covered the news about Archbishop Świątek's appointment and his reception of the cardinal's insignia at the consistory that took place on November 26-27, 1994.

\section{A Shepherd Among His Sheep: Kerygma and Catechesis}

The archbishop considered it his most important duty to serve the people entrusted to him in the most direct way: through the ministry of the Word, the celebration of the liturgy and the sacraments, and meeting the faithful in their parishes or places of residence. The archbishop's other duties were important to him insofar as they served his main purpose. Therefore, after settling the most urgent matters in the autumn of 1991, Archbishop Kazimierz Swiątek traveled to the parishes in his dioceses. These visits, later referred to as the first pastoral visits, differed from the typical canonical visits insofar as many parishes were still being organized and, consequently, did not have a church or a permanent priest. However, irrespective of the canonical side of these visits, they were inestimably valuable from a pastoral point of view. This shepherd strengthened Christ's followers who had remained faithful to Christ and testified to Him despite persecutions; he encouraged those who had kept the faith but did so deep within their hearts because they wanted to live peacefully; he proclaimed the mercy of God; and he called for the conversion of those who had rejected Christ.

Archbishop Świątek began his pastoral visits on the farthest outskirts of the archdiocese, since the people there had been waiting for a bishop for more than 70 years. On September 7, Archbishop Świątek arrived in Orsha, ${ }^{13}$ where one of the KGB's largest prisons from the

12 See “Zapowiedź Konsystorza," L’Osservatore Romano,” Polish Edition, vol. 15, no. 12 (1994): 58.

13 All data pertaining to the cardinal's canonical visits are based on the statements located in the private archives of His Excellency Cardinal K. Swiątek, which were made available to the author, TS. 
History of the Church

Stalinist era was located and where he himself had been imprisoned in 1945, was infected with typhus, and, consequently, fought for his life.

The next day, the archbishop drove $130 \mathrm{~km}$ from Orsha to Borisov. The following morning, he set off for almost $200 \mathrm{~km}$ to Braslavszczyzna. To begin, he visited the district of Miory on the Latvian border. On September 10, Archbishop Świątek arrived to Druia at the outskirts of his diocese. At that time, Druia was a poor settlement; before then, however, it had been a well-known city. During the Second Polish Republic, the Marians created a strong religious and educational center there. Currently there was a church and monastery in Druia that a member of the Marian order, Rev. Antoni Łoś, rebuilt.

Fr. Tadeusz Szeszko, FDP, witnessed Archbishop Świątek's meetings with the faithful. He recalled the following: "During the first pastoral visits, the faithful always reacted very emotionally, especially the elderly. There were always many people there. The churches were filled because not only Catholics but also Orthodox came. In many places, everyone in the surrounding area came. The archbishop never made a distinction between Catholics and Orthodox. He spoke to everyone who had gathered. His speeches and sermons were in Polish or, when people did not speak Polish, in Russian. Later on, he began to speak in Belarusian during his episcopal visits. During his sermons, he never spoke about his past and the wrongs he had suffered. Rather, he always strengthened and encouraged the people." 14

From Druia, Archbishop Świątek returned to Pińsk. Three days later, on September 13, 1991, he began his pastoral visits on the outskirts of that Diocese. He drove deep into his beloved Polesie forest toward Horyń and on to Lelczyce in the Homel District on the Ukrainian border. This was the most difficult and worst of all locations because it was a missionary territory affected by the terrible disaster at Chernobyl. Until then, the inhabitants had not received any pastoral care and they lived with the terrible memory of the bestial persecutions they suffered during the 1930s. It was not until June 1990 that Fr. Joseph Dziekoński came to Mozyrz to take care of the faithful of the Lelczyce district. Fr. Zbigniew Bojar, SCI, who was at the time starting to built the church in Lelczyce, and a group of the faithful greeted Archbishop Świątek at the church square.

During his visits, Archbishop Świątek consecrated the churches that the faithful were able to rebuild and prepare for worship. As Fr. Tadeusz Szeszko, FDP, shared, the archbishop conferred the

14 Based on the author's conversation with Fr. T. Szeszko, FDP, TS, and information found in the APKS. 
Sacrament of Confirmation in many parishes: "Usually a large group of the faithful received the Sacrament of Confirmation, since many people had secretly received their First Communion during the Soviet era. However, at that time, Confirmation almost never took place. So, since a lot of neglect occurred here, there were even groups of several dozen people ready to receive the Sacrament of Confirmation during the archbishop's initial pastoral visits." 15

Archbishop Świątek's pastoral visits usually proceeded as follows: the archbishop celebrated Mass and spoke to the people. Then he met with the local pastor, the church committee, and the faithful. These visits were interrupted only when the archbishop went to Rome for the Special Assembly of the Synod of Bishops dedicated to the topic of Europe, and they resumed on May 7, 1992.

The poverty of the shrines and the people, the simplicity of the people's faith, and the confusion and the spiritual emptiness of many of the faithful who the archbishop encountered during his visits did not discourage him. On the contrary, the archbishop believed that precisely the liturgy would reveal Christ to a people who had little or no knowledge of God. "The archbishop paid attention to the outer form of the celebration-the splendor of the liturgy. He tied this to the tradition from the time when the Servant of God Bishop Eoziński lived and to the rich liturgy of the East. He believed that the richness [and beauty] of the liturgy played an important pastoral role; it was a synthesized catechesis on conferring the sacrament. The archbishop always ensured that the liturgy was prepared well and that the celebrations revealed all its [spiritual] richness. This could be seen, for example, during the liturgy for the consecration of a church. In the West, and also in Poland, this liturgy has been very simplified. Yet, the original form of the liturgy is very rich. The archbishop always ensured that the dedication or consecration of a church contained all the proper liturgical elements and was fully celebrated. All the details had to be worked out and no shortcuts could be taken. For example, when the consecration takes place, the coal should be lit and the first fumigation of a church performed. At that time, not all priests had the appropriate vestments and vessels, so the archbishop ordered very large thuribles and we carried them with us. And he brought incense from Rome especially for us. He said to me, 'You have to hide and not use it because it is incense meant only for consecrations and visitations.' And when the incense was placed on the burning coals during the consecration or visitation, the entire church filled with fragrant

$15 \quad$ Ibid. 
History of the Church

smoke. A psalm had to be prepared and then sung at this moment. It was beautiful and had a deep pastoral significance-it was deeply meaningful!" 16

On October 8, 1992, in Slutsk Archbishop Świątek completed his pastoral visit to all 51 parishes in the Archdiocese. He also visited all 27 parish communities in the Diocese of Pinsk, ${ }^{17}$ and these visits ended on November 20, 1993 in Łahiszyn.

Cardinal Archbishop Świątek began his second pastoral visit on the farthest outskirts of the Diocese of Pinsk on September 3, 1998. He travelled from Żytkowicze and Lelczyce to Homel region, and then completed his visits with a canonical visitation to the cathedral in Pinsk on August 15, 1999. The first parish that the Archbishop visited in the Archdiocese of Mińsk-Mohilev was Chausy in the district of Mstislav, near the Russian border. The last parishes that the Cardinal Archbishop Świątek visited were in Mińsk, including the cathedral on November19, 1999, and, a week later, Sts. Simon and Helena parish, otherwise known as the "Red Church" located on the main square of the Belarusian capital. During Archbishop Świątek's second visit, Auxiliary Bishop Cyryl Klimowicz, who had ended his second pastoral visit of the Archdiocese on November 26, 2000, helped him. The last parish that he visited was Zaslav near Mińsk. Archbishop Świątek's second visit included 67 parishes in the Archdiocese of Mińsk-Mehilov, which had already been reduced to the parishes in the Vitebsk region, meaning the Diocese of Vitebsk, and 60 parishes in the diocese of Pinsk. ${ }^{18}$

Due to the narrow scope of this article, it is not possible to analyze Cardinal Archbishop Świątek's pastoral letters here. Nevertheless, these letters were a long-standing means both for Archbishop Świątek and in the tradition of the Catholic Church to proclaim the kerygma.

$16 \quad$ Ibid.

17 All data on the cardinal's canonical visits are based on His Excellency Cardinal K. Świątek's personal calendars and documents, TS, contained in his private archive.

18 This information is based on Cardinal K. Świątek's personal calendar and calculations, TS, contained in APKS. The new ordinary, Bishop Władysław Blin continued the canonical visitations within the Vitebsk voivodeship that were begun by Cardinal K. Świątek after the Diocese of Vitebsk was established on 10.13.1999. Based on Cardinal K. Świątek's personal calendar and statements, TS, contained in APKS. 


\section{Building the Church and Pastoral Management}

At the very beginning of his ministry, the archbishop himself was the only ecclesiastical authority in the province. There were no diocesan institutions. For this reason, the archbishop's apartment served as the Curia for the Archdiocese of Mińsk-Mohilev and Diocese of Pińsk, while Archbishop Świątek himself performed the duties of chancellor as well as all other duties necessary for the archdiocese and diocese to function. He was also de facto the parish priest of the cathedral in Pińsk.

The situation changed, however, when Fr. Tadeusz Szeszko, an Orionist, came from Poland to Pińsk. On September 21, 1991, Fr. Szeszko became the pastor of the cathedral in Pińsk as well as the chancellor of both Curias. However, since the Belarusian authorities did not give History their permission for him to work in Mińsk, Fr. Szeszko only acted duties of chancellor within the archdiocese. ${ }^{19}$ The chancellor began his work by arranging the bare minimum conditions necessary for both dioceses to function. In the bell tower next to the cathedral there were two rooms, which housed the Curia and served as the apartment of its only employee-the chancellor. Between the belfry and the wall surrounding the cathedral courtyard stood a wooden veranda, which served as the office and the only place where guests could be received. ${ }^{20}$

Due to the constant lack of priests, nuns, and laypersons, as well as the archbishop's very direct style of pastoral ministry and leadership, a strong organizational structure did not yet exist in Curia or was poorly developed. Instead, Curia's activities were based on the Archbishop's direct involvement in every area. The archbishop did this with the help of the chancellor, who served in this role for both dioceses (it was not until 2005 that Fr. Jerzy Kosobucki became the chancellor in Mińsk), and Sr. Sebastiana Elżbieta Grygiel, MSF, a graduate of the Faculty of Canon Law who began working in the Diocese of Pińsk on September 8, 1999. Archbishop Świątek did not underestimate the role of episcopal bishops in the governance of the dioceses; however, organizing them was of secondary importance to him. On several occasions the archbishop was heard to say: "I have the curia in my briefcase, so it is always ready at hand."

Pastoral issues were Archbishop Świątek's absolute priority. The then chancellor wrote the following on this topic: "Rebuilding the

19 See Archbishop K. Świątek, Dekret Administratora Apostolskiego Diecezji Pinskiej (09.21.1991) in the Archiwum Diecezji Pińskiej (ADP), 1. sec. 11/91.

20 Based on the author's interview with Fr. T. Szeszko, FDP, and on the author's own findings. 
History of the Church

spiritual Church was the most important for the archbishop. He did not even mobilize the priests to rebuild the parish buildings; instead, he urged them to organize the parishes by meeting with the faithful in their homes so that they could receive spiritual care, so that their faith could be rebuilt." ${ }^{21}$

After the chancellor was appointed, vicar generals were chosen. In the Diocese of Pińsk, Fr. Kazimierz Wielikosielec, OP, then a parish priest in Baranavichy, was appointed Vicar General on May 12, 1992. And, in the Archdiocese of Mińsk-Mohilev, Fr. Lucjan Chmielowiec, who had been ordained a parish priest in Derewna, was appointed Vicar General on September 24, 1992. ${ }^{22}$

The nature of Archbishop Świątek's pastoral ministry and his sensitivity to the needs of the weak and disadvantaged are evidenced by the fact that Caritas was the next institution that he established in both dioceses on December 21, 1992. Caritas was established nationally seven years later on August 30, $1999 .^{23}$

It was impossible to appoint the ecclesiastical courts quickly due to the lack of staff. For this reason, the ordinary bishops established an interdiocesan court, which had yet to obtain the Holy See's official approval. For the time being, however, it was the only possible practical solution. On December 4, 1993, Archbishop Świątek established in Mińsk an interdiocesan tribunal for the Archdiocese of Mińsk-Mohilev and the Diocese of Pinsk (Latin rite). The Tribunal was erected on January 25, 1994, and served simultaneously as the Appelate Court for the Interdiocesan Tribunal in Grodno for the Diocese of Grodno and for the Apostolic Administrations of European Russia, Siberia, and Kazakhstan (Latin rite). On the same day, Archbishop Świątek issued two decrees in Mińsk and Pińsk appointing the judicial vicar, judges, defenders of the bond, promoters of justice, and notaries. ${ }^{24}$ After the Apostolic Signatura approved the Tribunal on May 16, 1994,

21 From the record of the author's conversation with Fr. T. Szeszko, FDP, TS and information contained in APSK.

22 See Archbishop K. Świątek, Dekret Administratora Apostolskiego Diecezji Pińskiej (05.12.1992), in ADP, 1. sec. 55/92; Archbishop K. Świątek, Dekret Metropolity Mińsko-Mohylewskiego (09.24.1992), in Archiwum Archidiecezji Mińsko-Mohylewskiej (AAMM), 1. sec. 126/92.

23 APKS, information about the state of the metropolis, TS, copy available in the APSK.

24 See Archbishop K. Świątek, Dekret Metropolity Mińsko-Mohylewskiego (01.25.1994), in AAMM, 1. sec.13/94 m-m. 01/94, as well as Archbishop K. Świątek, Dekret Administratora Apostolskiego Diecezji Pińskiej (01.25.1994), in ADP, 1. sec. 14/94 02/94; See MMPA 1, no. 1 (1998), 26; PPD 1, no. 1 (1998), 26. 
Archbishop Świątek issued a decree on September 17, 1994 that the work of the Tribunal would begin the following month on October 1, $1994 .{ }^{25}$

Because of Archbishop Świątek's concern for the "integrity of the faith and morals" as well as the diocesan publishing house's activities, he appointed separate censors for the Archdiocese of Mińsk-Mehilov and Diocese of Pińsk on January 25, $1994 .{ }^{26}$ On the same day, in accordance with Canon 495, members of the Council of Priests were appointed for the diocese and archdiocese. ${ }^{27}$ Archbishop Świątek also appointed catechetical councils to ensure the unity of the catechesis program and the efficient work of the catechists on January 25, 1994 within the diocese and on May 7 of the same year in the archdiocese. ${ }^{28}$

In order to coordinate activities related to the reconstruction and renovation of shrines and other church buildings, Archbishop Świątek and the Ordinary of Grodno established the Arcybiskupi Urząd Budowlany [Archbishop's Office for Construction] for the dioceses in Belarus on November 5,1994 . The office was subordinate to the archbishop, and its headquarters were in Baranovichi. ${ }^{29}$

Some of the faithful and priests who identified with the tradition and heritage of the Belarusian People's Republic and were now associated with the Belarusian National Front sought to have the liturgy celebrated in Belarusian. Since there was an insufficient number of missals, lectionaries, agendas, texts containing the ceremonies, rituals, and other books in the Belarusian language, private translations were used. These unofficial translations made the threat of liturgical

25 SeeArchbishop K. Świątek, Dekret Metropolity Mińsko-Mohylewskiego iAdministratora Diecezji Pinskiej (09.17.1994), in ADP, l. sec. 166/94 10/94; see MMPA 1, no. 1 (1998), 27; PPD 1, no. 1 (1998), 27.

See Archbishop K. Świątek, Dekret Metropolity Mińsko-Mohylewskiego (01.25.1994), in AAMM, 1. sec. 18/94 m-m; Archbishop K. Świątek, Dekret Administratora Apostolskiego Diecezji Pinskiej (01.25.1994), in ADP, 1. sec. 19/94p.

See Archbishop K. Świątek, Dekret Metropolity Mińsko-Mohylewskiego (01.25.1994), in AAMM, 1. sec. 17/94 m-m. The following decrees were published on 05.09.19941. sec. 13a/94 and on 09.30.19951. sec. 15/95; Archbishop K. Świątek, Dekret Administratora Apostolskiego Diecezji Pińskiej (01.25.1994) ADP, 1. sec. $15 / 94 \mathrm{p}$, the following decrees were published on 05.04 .1995 l. sec. $01 / 95$ and on 12.22.1995 1. sec. 07/95.

See Archbishop K. Świątek, Dekret Metropolity Mińsko-Mohylewskiego (05.07.1994), in AAMM, 1. sec. 84/94 13/94; See Archbishop K. Świątek, Dekret Administratora Apostolskiego Diecezji Pińskiej (01.25.1994), in ADP, 1. sec. 16/94p and on (12.11.1994) l. sec. 18/94.

29 See Archbishop K. Świątek and Bishop A. Kaszkiewicz, Akt Założycielski Arcybiskupiego Urzędu Budowlanego (Pinsk: 11.05.1994), in ADP, 1. sec. 15b/94. 
History of the Church

abuse of the Eucharist a reality, since they could contain incorrect liturgical formulas that could invalidate the celebration of the Mass. Therefore, after pointing out this danger to the priests, Archbishop Świątek met with the Apostolic See to obtain approval for the consecration and sacramental formulas to be translated into Belarusian. The Congregation for Divine Worship and Discipline of the Sacraments approved the translations on July 12, 1994. Through a decree issued on July 28, 1994, the Archbishop introduced the formulas as permissible only during the celebration of the liturgy in Belarusian. In order to resolve the complex problem of the lack of liturgical books in Belarusian, Archbishop Świątek, in agreement with the Bishop of Grodno, appointed the Standing Committee for the Translation of Liturgical Texts on May 5, 1995. The Commission worked diligently and quickly prepared, among other things, a standard Missal edytio typica tertia in Belarusian language. ${ }^{30}$

Archbishop of Swiątek also created a College of Consultants in both dioceses. The members of this college were appointed for a five-year term. The College was established in the Diocese of Pinsk on December 22, 1995, and in the Archdiocese of Mińsk-Mohilev on February $5,1996 .{ }^{31}$

The Archbishop once again linked his pastoral activity to his master and predecessor, Bishop Zygmunt Łoziński, by establishing official magazines for both dioceses on December 28, 1997. In the Diocese of Pińsk, he resumed the "Piński Przegląd Diecezjalny [The Pińsk Diocesan Review]," and, recalling the "Miesięcznik Diecezji Mińskiej [The Diocese of Mińsk Monthly]," he established the "Mińsko-Mohylewski Przegląd Archidiecezjalny [Mińsk-Mogilev Archdiocesan Review]." 32

Although the cathedral chapter in Pińsk existed when Bishop Zygmunt Łoziński governed, Archbishop Kazimierz Świątek never found

$30 \quad$ Fr. Władysław Zawalniuk published his own translation of the liturgical books. See Congregation for Divine Worship and the Discipline of the Sacraments, Decree (July 12, 1994) 1. sec. Prot. 660/93/L, MMPA 1, no. 1 (1998), 11-13; Archbishop K. Świątek, Dekret Metropolity Minsko-Mohylewskiego (07.28.1994), in AAMM, 1. sec. 136/94, 18/94; Archbishop K. Świątek, Dekret Administratora Apostolskiego Diecezji Pińskiej (07.28.1994), in ADP, 1. sec. 07/94.

31 See Archbishop K. Świątek, Dekret Metropolity Mińsko-Mohylewskiego z (02.05.1996), in AAMM, 1. sec. 19/96; Archbishop K. Świątek, Dekret Administratora Apostolskiego Diecezji Pińskiej (12.22.1995), in ADP, 1. sec. 08/96.

32 Archbishop K. Świątek, Dekret Administratora Apostolskiego Diecezji Pińskiej (12.28.1997), in ADP, 1. sec. 26/97; and Archbishop K. Świątek, Dekret Metropolity Mińsko-Mohylewskiego (12.28.1997), in AAMM, 1. sec. 56/97. 
it necessary to set up any cathedral chapters during his episcopal ministry.

\section{Establishing a Network of Parishes and Deaneries}

Even though the ordinary structure of the Catholic Church had been completely established in the territory of the BSSR according to Church law, the Church's legal status under civil law had not changed. The collapse of Communism in the countries that were under Moscow's rule affected the atmosphere that dominated the Soviet Empire; primarily, it reduced the peoples' fear of repression. While the anti-Church decrees of 1918 and 1922 were still in force, the change in social sentiment led to the creation of church committees throughout Belarus that sought to register and, where possible, have their rightful shrines returned to them.

With the formation of subsequent parishes, a deanery was introduced in the Archdiocese of Mińsk-Mohilev and the Diocese of Pińsk. Although normal and based in tradition, the introduction of the deanery and deans made some priests, who were used to the archbishop making all decisions, recommendations, and remarks, uncomfortable with the idea that these decisions would come through the deans. In the Diocese of Pinsk, the deanery was introduced on June 8, 1992. Since the network of parishes in this diocese was still being established, the boundaries of the 5 deaneries were defined territorially and based on state administrative units. ${ }^{33}$ In the Archdiocese of Minsk-Mehilov, the deanery structure was introduced later on November 7, 1993. Just as in the Diocese of Pińsk, the boundaries of the 11 new deaneries in the Archdiocese of Mińsk-Mehilov were also determined territorially. ${ }^{34}$

The analysis of the deanery network and personal nominations makes it very clear that the parish and deanery network were extremely diversified during the first years of Archbishop Świątek's pastoral service. Despite the dynamism and rebirth of Catholicism in Belarus, by the end of 1993 there was still much for the archbishop to do to establish a strong network of parishes. While Catholics were fairly organized into parish communities and formed a relatively dense network in western and central Belarus, in eastern Belarus there were few communities and a network of parishes was not very dense.

33 See Archbishop K. Świątek, Dekret Administratora Apostolskiego Diecezji Pińskiej (06.08.1992), in ADP, 1. sec. 71/92; see PPD 1, no. 1 (1998), 22-23.

34 SeeArchbishopK.Świątek,DekretMetropolityMińsko-Mohylewskiego (11.7.1993), in AAMM, 1. sec. 146/93 (09/93); see MMPA 1, no. 1 (1998), 23-24. 
History of the Church

In addition, there were not necessarily parishes in all of the localities designated as the capitals of the deaneries. Therefore, sometimes the deans did not reside permanently in these localities.

Nevertheless, the dynamic development of the network of parishes under the archbishop's care is striking. According to official Soviet records from early 1991, 222 Catholic religious communities, meaning registered church communities, were recorded throughout Belarus. ${ }^{35}$ The vast majority of communities were in the Diocese of Grodno. At that time, there were about 20 parishes in the Diocese of Pinsk, and about 15 parish communities in the Archdiocese of Mińsk-Mohilev. ${ }^{36}$ By the end of 1992, there were 51 parishes in the archdiocese, and 27 parishes in the diocese one year later. ${ }^{37} \mathrm{By}$ the end of 1994, there were 310 parishes in Belarus, worship took place in 260 of these churches, and 35 shrines were being built. ${ }^{38}$ Although most parishes were still in the Diocese of Grodno, the Church developed dynamically throughout the country. At the end of 2000 , there were 60 parishes in the Diocese of Pińsk and 79 parishes in the Archdiocese of Mińsk-Mohilev. Considering the fact that the whole area of the voivodship where there were 53 parishes was excluded from the archdiocese and incorporated into the newly created Diocese of Vitebsk, it is clear that the development of the Church has been incredibly dynamic since 1991.

Unfortunately, because of the great lack of priests, many parishes still did not have a resident parish priest. In 2000, 31 of the parishes in the Archdiocese of Mińsk-Mohilev, which did not yet include the Diocese of Vitebsk, did not have a permanent parish priest (note: there were 38 such parishes throughout the archdiocese in 1991). In 2000, 28 parishes did not have a parish priest in residence in the Diocese of Pińsk (note: there were 19 such parishes in 1991).

Throughout Archbishop Świątek's entire pastoral appointment, priests from religious communities greatly contributed to parish ministry. In 1991, religious priests ran 19 parishes and diocesan priests ran 25 parishes in the Archdiocese of Mińsk-Mohilev, and religious priests ran 9 parishes while diocesan priests ran 8 parishes in the Diocese of Pińsk. In 2000, these proportions changed further in the favor of

35 See J. Karłow, Missja w Watykan (Moscow: 2004), 162.

$36 \quad$ Based on the author's own calculations.

37 All data regarding the cardinal's canonical visitations are based on his personal calendar and statements located in Cardinal K. Świątek's private archives, TS.

38 Based on His Excellency Cardinal K. Świątek's estimates; see W. Rędziocha interview with Cardinal K. Świątek, "Przeżył 10 lat gułagu rozmowa," Niedziela: Tygodnik katolicki, vol. 27, no. 51A (1994): 5. 
religious priests, such that there were the same number of parishes led by religious priests as there were parishes led by diocesan priest within the archdiocese: more than 24 each; whereas, in the diocese, 20 parishes were led by religious priests, and only 12 were led by diocesan priests. ${ }^{39}$ While there were only 6 religious sisters in the archdiocese and 3 religious sisters in the diocese in 1991, there were 68 religious sisters in the archdiocese and 52 religious sisters in the diocese in $2000 .{ }^{40}$

\section{Forming New Presbyters}

The sacrifices made by a few local and Polish priests made it possible for the most urgent pastoral needs to be met and for the infrastructural foundations of the Archdiocese of Minsk-Mohilev to be established. Further development was impossible without the immediate formaHistory of the Church tion of priests. Therefore, at the beginning of his ministry, Archbishop Kazimierz Świątek decided to revive the seminary in Pińsk, where he had finished his studies. ${ }^{41}$ At that time, the Red Army occupied the seminary, and it was not until November 3, 1993 that some of the devastated seminary buildings were handed back over to the Church. It took several years for the remaining buildings to be restored to the Church and then renovated.

On May 31, 2001, the Congregation for Catholic Education (Seminaries and Educational Institutions) approved the seminary and its statutes. ${ }^{42}$ The seminary was to serve the Archdiocese, the Diocese of Pińsk, and the Diocese of Vitebsk. On July 21, 2001, as the President of the Bishops Conference of three dioceses and the bishop of the place, Cardinal Archbishop Kazimierz Świątek erected the Interdiocesan Higher Seminary of St. Thomas Aquinas in Pińsk. ${ }^{43}$

On September 12, 2001, the seminary for priests in Pinsk resumed its activity after being forced to close for 62 years. Cardinal Kazimierz Świątek served as the temporary rector of the seminary. He also nominated 10 professors and 4 administrators and accepted 14 seminarians

$39 \quad$ APSK, based on information provided to the author by His Excellency Cardinal K. Świątek, TS.

$40 \quad$ Ibid.

41 APSK, based on the author's interview with His Excellency Cardinal K. Świątek.

42 See Congregatio de Institutione Catholica (de Seminariis atque Studiorum Institutis), Dekret (05.31.2001), Prot. N621/2001/7, ADP.

$43 \quad$ See Ibid. 
for their first year of study. ${ }^{44}$ Opening the seminary was the final step necessary for Archbishop Świątek to complete the process of establishing and developing the particular Church structures entrusted to his care.

\section{The Synod}

During his fourth year of episcopal ministry, Archbishop Kazimierz Świątek publicized his intention to convene a synod before all of the priests who were gathered for a day of recollection. Shortly thereafter, in accordance with Canon 461, Par.1 of the Code of Canon Law, the archbishop gathered the Council of Priests to hear their opinion

History of the Church on December 21, 1995 in the Diocese of Pinsk and on December 28, 1995 in the Archdiocese of Mińsk-Mohilev, respectively. Both Councils unanimously and enthusiastically accepted the proposal. ${ }^{45}$

On February 5, 1996, Cardinal Kazimierz Świątek issued a decree and appointed an Organizational Committee comprised of 5 members "to complete the preparatory work" for the synod. ${ }^{46}$ The members of the Organizational Committee met three times ${ }^{47}$ and presented their work to the archbishop, who considered it satisfactory. On April 14,1996 , the archbishop issued a decree that ended the committee's

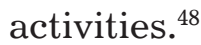

On the Feast of the Annunciation in 1996, Cardinal Kazimierz Swiątek issued a decree that convened the synod, presented its aims, and announced that the synod would begin on September 29, 1996,

44 "Otwarcie Seminarium duchownego w Pińsku," Niedziela: Tygodnik katolicki, vol. 34, no. 32 (2001): 5.

45 See[S.Pawlina], "Dlaczego Synod Archidiecezji Mińsko-Mohylewskiej i Diecezji Pińskiej?,” PPD, vol. 1, no. 2 (1998), 4.

46 The archdiocesan priests were: Fr. Zbigniew Bojar, SCJ; Fr. Czesław Kucmierz, SCJ; and Fr. Wojciech Lemański. The diocesan priests were: Fr. Jerzy Mazur, SVD, and Fr. Stanisław Pawlina, FDP. See Archbishop K. Świątek, Dekret Metropolity Mińsko-Mohylewskiego, Administratora Apostolskiego Diecezji Pińskiej (02.05.1996), in AAMM 1. sec. N.20/96.

47 The Organizational Committee for the Synod met on 02.07.1996 in Postawa as well as on 02.29.1996 and 03.28.1996 in Baranowicz. See S. Pawlina, "Wprowadzenie [do Statutów Synodu]," Statuty Synodu Archidiecezji Mińsko-Mohylewskiej, Diecezji Pinskiej i Witebskiej (Minsk: 2002), 371.

48 See Archbishop K. Świątek, Dekret Metropolity Minsko-Mohylewskiego, Administratora Apostolskiego Diecezji Pińskiej (04.14.1996), in AAMM 1. sec. N.129a/96-27b/96. 
the Feast of the Archangels Michael, Raphael, and Gabriel..$^{49}$ During the course of the synod, Pope John Paul II established the Diocese of Vitebsk and appointed its own bishop, thereby separating it from the Archdiocese of Mińsk-Mohilev in 1999. The new ordinary, Bishop Władysław Blin, turned to Cardinal Kazimierz Świątek to ask that together they complete the work of the synod and include in it the Diocese of Vitebsk. The cardinal archbishop gave his consent and, the from then on, the synod was called the "Synod of the Archdiocese of Mińsk-Mohilev, the Diocese of Pińsk, and the Diocese of Vitebsk." In turn, by a decree issued on December 20,1999, the Bishop of Vitebsk recognized the work of the synod, its acts, and resolutions that had occurred thus far as his own..$^{50}$

By the decree of April 14, 1996, Cardinal Kazimierz Świątek appointed the Coordinating Commission for the Synod of the Archdiocese of Mińsk-Mohilev and the Diocese of Pińsk (CCS), whose task was to direct all matters related to the work of the synod. Cardinal Kazimierz Świątek served as the Chairman of the CCS, while the Vice-Chairman was the Chancellor of the Curia, Fr. Stanisław Pawlina, FDP, who also prepared the meeting schedule for the CCS and led the meetings according to the Cardinal's orders. Moreover, the CCS consisted of 5 priests from the archdiocese and 2 priests from the diocese.$^{51}$ During the synod, they specified the Statutes of the Synod of the Archdiocese of Minsk-Mohilev and the Diocese of Pinsk and its part of the regulations. ${ }^{52}$

According to Cardinal Kazimierz Świątek, the Synod was not to be confined strictly to those involved in it; rather, it should allow for a wide range of pastoral and formation activities and include the entire particular Church. The Synod of the Archdiocese of Minsk-Mohilev and the Diocese of Pinsk officially opened in the cathedral in Mińsk

$49 \quad$ See Archbishop K. Świątek, Dekret Metropolity Mińsko-Mohylewskiego, Administratora Apostolskiego Diecezji Pinskiej(03.25.1996), in AAMM, l. sec. N.121/96.

50 See Władysław Blin,Dekretprzyjęcia SynoduArchidiecezji mińsko-mohylewskiej i Diecezji pińskiej w Diecezji witebskiej (Vitebsk: 12:20.1999) [bez l. sec.]; see MMPA 3, no. 1 (2000), 21-22.

51 Initially, they were: Fr. Cyryl Klimowicz; Fr. Czesław Kucmierz, SCJ; Fr. Wojciech Lemański; Fr. Jerzy Mazur, SVD; Fr. Henryk Okołotowicz; Fr. Jan Salamon; and Fr. Władysław Zawalniuk. See Archbishop K. Świątek, Dekret Metropolity Mińsko-Mohylewskiego, Administratora Diecezji Pińskiej(04.14.1996), in AAMM 1. sec.129/96. In the years that followed, Archbishop K. Swiątek changed the makeup of the group as the roles and obligations of the group members changed (i.e. bishops were nominated). After two months, Fr. W. Lemański resigned from working with Archbishop K. Świątek.

52 See Cardinal K. Świątek, Statut Synodu Archidiecezji mińsko-Mohylewskiej i Diecezji Pińskiej (05.24.1996), in AAMM 1. sec. 181a/96. 
on September 29, 1996. Cardinal Kazimierz Świątek presided over the Holy Mass. Pope John Paul II sent his apostolic blessing and greetings to Cardinal Swiątek on the occasion of the solemn commencement of the synod.

Throughout the duration of the synod, parishioners prayed for the meeting's success. So many people participated in this prayer that it was a great pastoral effort. The daily program included the celebration of the Holy Mass, a homily, the Sacrament of Confession, adoration of the Most Blessed Sacrament, the Rosary, catechesis, and other prayers. The sick and disabled were encouraged to offer their prayers and sufferings in the intention of the synod. ${ }^{53}$

On September 30, 2000, the synod was solemnly closed in Mińsk. The

History of the Church Holy Father sent a special envoy, Cardinal Camillo Ruini, Vicar General of the Diocese of Rome. On that day, all synodal resolutions were solemnly promulgated when Cardinal Archbishop Kazimierz Świątek, the Administrator of the Diocese of Pinsk, and Bishop Władysław Blin of the Diocese of Vitebsk issued decrees stipulating that all the statutes adopted during the synod become law in the three dioceses beginning on January $6,2001 .^{54}$

\section{Other Dimensions of the Archbishop's Service}

The narrow scope of this article makes it necessary to end with a few of Archbishop Świątek's other important accomplishments. At the end of 1994, the archbishop organized an editorial office in Mińsk, which began by publishing the monthly publication "Ave Maria." In the years that followed, the office also published the quarterly "Nasza Wiara [Our Faith]," the bulletins "Wiadomości katolickie [Catholic News]," as well as "Mały rycerzyk Niepokalanej [The Little Knight of the Immaculate]" for children. All publications appeared in Belarusian. On January 13, 2000, the Archbishop of Mińsk-Mohilev established a publishing house named "Pro Christo" that was registered with the state.

The people of God in Belarus have honored the Mother of Christ for centuries. There are many shrines dedicated to the Blessed Virgin Mary. Mary also had a special place in Archbishop Świątek's heart since he was a child. When he was a young student, he belonged to the Sodalis Marianus. As part of this sodality, the young Kazimierz

53 See Ibid, 29-31, 50-70.

54 See Archbishop K. Świątek, Dekret Metropolity Mińsko-Mohylewskiego, Administratora Apostolskiego Diecezji Pinskiej (09.30.2000), 1. sec. M-M 30/2000; Władysław Blin, Bishop of the Diocese of Vitebsk, Dekret, (09.30.2000) ADW, 1. sec. $303 / 2000 / \mathrm{Bp}$. 
Świątek carried a rosary with him wherever he went, and he prayed the Marian prayers as a priest, archbishop, and cardinal. The title of Mary as Mater misericordiae can be found on his episcopal insignia. Therefore, it was natural for the archbishop to establish Marian shrines within his archdiocese. To this end, on July 2, 1998, Cardinal Kazimierz Swiątek crowned the miraculous image of Our Lady of Budsław in the name of Pope John Paul II, and, on the same day, issued a decree that declared the shrine a national "MARIAN SANCTUARY" for the entire country of Belarus. ${ }^{55}$ From then on, the sanctuary was and continues to be called the National Shrine of Belarus.

In the Diocese of Pinsk, there are two images of the Blessed Virgin in Brest and Eahiszyn that have been honored by the faithful for centuries. On May 10, 1997, in the name of the Holy Father, Cardinal Kazimierz Świątek crowned the Child Jesus and the Mother of God History of the Church in the sanctuary in Łahiszyn. On the same day, he issued a decree declaring the shrine as the Sanctuary of the Diocese of Pinsk ${ }^{56}$ In addition, on June 30, 1996, in the name of Pope John Paul II and by his authority, Cardinal Kazimierz Świątek crowned the image of the Child Jesus and His Mother located in the Church of the Exaltation of the Holy Cross in Brest. ${ }^{57}$ While the archbishop did not issue a decree to erect a sanctuary in this place, the statues of the synod granted this church the title (of sanctuary). ${ }^{58}$

\section{Conclusion}

The narrow scope of this article makes it possible to describe only the most important achievements of Fr. Kazimierz Świątek's episcopal ministry. Called to serve as Metropolitan of Mińsk and as Apostolic Administrator of Pińsk in 1991, Archbishop Kazimierz Świątek was entrusted with the pastoral care of a territory that covered almost $90 \%$ of Belarus. Remarkably, at the time he began his ministry, there were almost no priests, no churches, and only a few active faithful. Although he was 77 years old, Fr. Kazimierz Świątek greatly mobilized the rebuilding of the physical and spiritual Church in Belarus. When

55 See Archbishop K. Świątek, Dekret Arcybiskupa Metropolity MińskoMohylewskiego (07.02.1998), in AAMM, 1. sec. 18/98. (05.10.1997), in ADP, 1. sec. 05/03, copy available in the APSK. Nasza Wiara, no. 1 (1996): 18. 
History of the Church

Archbishop Kazimierz Świątek assumed his episcopal office, the average distance between shrines and parishes was $300 \mathrm{~km}$; however, ten years after he began his ministry, that number was reduced to only 30 $\mathrm{km} .{ }^{59}$ As the distance between parishes decreased, so did the number of the faithful increase dynamically. At that time, he also successfully managed to lead a synod. When the Archbishop resigned in 2006, the Church in Belarus had a an infrastructure, diocesan curia, a relatively dense network of parishes, sanctuaries, seminaries, catechetical institutes, publishing houses, and its own challenging but stable religious communities.

According to the archbishop, the parish is the primary place where the Church of Christ is realized. The archbishop praised the people's traditional forms of piety, believed that they should be cultivated, and was convinced that the identity of the particular Church was expressed in them. For, thanks to popular piety, the Church in Belarus was preserved during Communism.

The Archbishop's episcopal ministry was characterized by a great simplicity, directness, kindness, and openness. Despite his dignity as an archbishop and cardinal, Fr. Kazimierz Świątek remained a humble shepherd of souls, carrying on the work that he had begun as a parish priest in the cathedral in Pinsk. When he met with the faithful, they were most touched by the way that the archbishop talked with them, listened to them, joked with them, and gave them advice. He was, in the words of Christ, "a good shepherd [who knew] his sheep." Among other things, the bishop took to heart that which his faithful suffered; their concerns were his concerns. Archbishop Świątek did not lack in fatherly love, and his episcopal ministry was guided by the following from Isaiah: "a dimly burning wick he will not quench." ${ }^{60}$ He acted like the merciful Samaritan, rather than a severe bishop who desired to use the authority that Christ had given to him to judge and govern. This was true of his attitude toward both the faithful and the priests. This approach to episcopal ministry is deeply rooted in the Tradition of the Church.

Archbishop Świątek was a father for priests and religious sisters. $\mathrm{He}$ respected and appreciated them, but he placed high moral demands on them and expected them to fulfill their duties. He believed that priests should unreservedly devote themselves to the salvation of the People of God. However, a discussion of this issue must be taken up in a subsequent publication.

$59 \quad$ See Ibid.

60 Isaiah 42:3. 


\section{POSŁUGA BISKUPIA KSIĘDZA KAZIMIERZA ŚWIĄTKA (1914-2011)}

W artykule przedstawiono zasadnicze wątki posługi pasterskiej ks. arcybiskupa Kazimierza Świątka, który przez pięćdziesiąt dwa lata świadczył o Chrystusie jako ksiądz, a przez następnych niemal dwadzieścia lat, jako arcybiskup i kardynał. Kiedy ksiądz Kazimierz Świątek po latach sowieckiego ucisku obejmował kanonicznie odpowiedzialność za metropolię mińsko-mohylewską i diecezję pińską Kościół instytucjonalny w nich niemal nie istniał. Niewiele lepiej było w wymiarze wiary ludu. Kiedy zakończył swoją posługę biskupią prowincja kościelna miała wszystkie instytucje niezbędne do normalnego funkcjonowania, a kościoły zapełniły się wiernymi. Ten Pasterz wpisuje się w długą listę gorliwych biskupów Kościoła Chrystusowego. Artykuł obejmuje okres posługi biskupiej księdza Kazimierza Świątka. Czas prezbiteratu przedstawiłem we History of the Church wcześniejszej publikacji

Słowa kluczowe: pasterz, biskup, posługa, kerygma, ewangelizacja, duchowe dewastacje, komunizm, odbudowa Kościoła, potrzeby wiernych, Pińsk, Mińsk-Mohylew.

\section{Bibliography:}

1. Królak, S.M. "Wierność powołaniu-ksiądz Kazimierz Świątek (19142011)." Rocznik Teologii Katolickiej, Vol. XV, No. 1 (2016): 149-179.

2. "Przywrócenie struktur kościelnych na Ukrainie." L'Osservatore Romano. Polish Edition. Vol. 12, No. 2-3 (1991): 29.

3. Karłow, J. E. Missja w Watykan. Moscow: 2004.

4. John Paul II. Bulla "Ex quadam praeteritorum, Constittutiones Apostolicae. I. Minscensis-Mohiloviensis Latinorum. Minscensis-Mohiloviensis Latinorum conditur archidioecessis." In Acta Apostolicae Sedis: Commentarium Officiale. Vol. 83, No. 7. Romae: Typis Polygottis Vaticanis, 1991, 540-541.

5. John Paul II. Bulla "Qui operam damus, Constittutiones Apostolicae. I. Minscensis-Mohiloviensis Latinorum. Minscensis-Mohiloviensis Latinorum conditur archidioecessis." In Acta Apostolicae Sedis: Commentarium Officiale. Vol. 83, No. 7. Romae: Typis Polygottis Vaticanis, 1991, 540-542.

6. John Paul II. Bulla "Quia ob rerum, Constittutiones Apostolicae. I. Minscensis-Mohiloviensis Latinorum. Minscensis-Mohiloviensis Latinorum conditur archidioecessis." In Acta Apostolicae Sedis: Commentarium Officiale. Vol. 83, No. 7. Romae: Typis Polygottis Vaticanis, 1991, 542-543.

7. Nitecki, P. Biskupi Kościoła w Polsce w latach 965-1999: stownik biograficzny. Warsaw: Instytut Wydawniczy PAX, 2000.

8. "Zapowiedź Konsystorza." L'Osservatore Romano. Polish Edition. Vol. 15, No. $12,58$. 
9. Terlecki, E. "Karanacyja cudadzejnaga abraza Maci Bożaj Berascejskaj." Nasza Wiara. No. 1 (1996): 18.

10. Statuty Synodu Archidiecezji Mińsko-Mohylewskiej, Diecezji Pinskiej $i$ Witebskiej. Minsk: 2002.

11. "Otwarcie Seminarium duchownego w Pińsku." Niedziela. Tygodnik katolicki. Vol. 34, No. 38 (2001): 5.

12. "Dlaczego Synod Archidiecezji Mińsko-Mohylewskiej i Diecezji Pińskiej?" Pinski Przeglad Diecezjalny. Vol. 1, No. 2 (1998): 4.

13. Pawlina, S. "Wprowadzenie [do Statutów Synodu]." Statuty Synodu Archidiecezji Mińsko-Mohylewskiej, Diecezji Pińskiej i Witebskiej. Minsk: 2002, 351-371. 